\title{
UNC45A wt Allele
}

National Cancer Institute

\section{Source}

National Cancer Institute. UNC45A wt Allele. NCI Thesaurus. Code C101386.

Human UNC45A wild-type allele is located in the vicinity of 15q26.1 and is approximately $24 \mathrm{~kb}$ in length. This allele, which encodes protein unc- 45 homolog $\mathrm{A}$, is involved in both cell differentiation and muscle development. 